\title{
Peningkatan Keterampilan Menulis Narasi Melalui Model Concept Sentence Peserta Didik Kelas V Sekolah Dasar
}

\section{Ria Dwi Wulandari}

Universitas Sebelas Maret

riadwiwulan@gmail.com

\section{Article History}

received 30/4/2021

\begin{abstract}
This study aimed to increase the narrative writing skill by using Concept Sentence model of the fifth-grade students at Public Elementary School Soko 1 in the academic year 2020/2021. The study was Classroom Action Research. The subjects of this research were teacher and 12 fifth grade students. The finding of this research shows that the application of Concept Sentence model can improve narrative writing skills students. It can be compares to the score result in the pretest and each cycle. The classical completeness score in the pretest is $25 \%$, and then up to 58,33 in the cycle one, in the cycle II increased to $75 \%$, and in the cycle III increased again to 91,67\%. Based on results research, can concluded that application of Concept Sentence model can improve narrative writing skills of fifth grade students at Public Elementary School Soko 1 in the academic year 2020/2021.
\end{abstract}

Keywords: Concept Sentence model, narrative writing skill, Elementary School

\section{Abstrak}

Tujuan penelitian ini adalah untuk meningkatkan keterampilan menulis narasi melalui model pembelajaran Concept Sentence pada peserta didik kelas V SD Negeri Soko 1 tahun ajaran 2020/2021. Penelitian ini merupakan Penelitian Tindakan Kelas. Subjek dari penelitian ini merupakan guru kelas dan 12 peserta didik kelas V. Hasil penelitian ini menunjukkan bahwa penggunaan model pembelajaran Concept Sentence dapat meningkatkan keterampilan menulis narasi. Hal ini dapat dapat dibandingkan dari hasil nilai pratindakan dengan nilai di tiap siklus. Perolehan ketuntasan klasikal pada saat pratindakan sebesar $25 \%$, meningkat menjadi 58,33\% pada siklus I, di siklus II meningkat menjadi $75 \%$, dan pada siklus III juga mengalami peningkatan menjadi $91,67 \%$. Berdasarkan hasil penelitian, dapat disimpulkan bahwa penggunaan model Concept Sentence dapat meningkatkan keterampilan menulis narasi peserta didik kelas V SD Negeri Soko 1 tahun ajaran 2020/2021.

Kata kunci: model concept sentence, keterampilan menulis narasi, sekolah dasar 


\section{PENDAHULUAN}

Bahasa merupakan alat yang dapat mempermudah manusia dalam melakukan komunikasi atau interaksi dengan manusia yang lain. Kemampuan anak dalam berbahasa tidak diperoleh secara langsung, akan tetapi melalui suatu tahapan tertentu. Anak tidak dapat langsung menguasai suatu bahasa dengan baik dan benar, tetapi melalui proses belajar dan latihan yang dilaksanakan secara bertahap serta terusmenerus. Uraian tersebut sependapat dengan yang disampaikan oleh Slamet (2014) bahwa proses peningkatan anak dalam berbahasa didapatkan sejalan dengan dengan perkembangan anak dalam hal intelektual, mental, fisik serta sosial.

Bahasa Indonesia wajib dikuasai dalam kehidupan bermasyarakat, terutama dalam bidang pendidikan. Hal tersebut dikarenakan dalam proses pembelajaran di kelas menggunakan bahasa Indonesia sebagai bahasa pengantar, baik secara lisan maupun tertulis. Keterampilan bahasa yang diterima peserta didik dalam pembelajaran bahasa Indonesia terdiri dari beberapa aspek. Tarigan (2008) mengemukan bahwa aspek dalam keterampilan berbahasa manusia adalah keterampilan menulis, membaca, berbicara, dan menyimak. Keempat aspek keterampilan tersebut berkaitan satu dengan yang lain dan tidak dapat dipisah. Menurut perkembangannya, keterampilan menulis lebih rumit dibandingkan dengan keempat keterampilan bahasa yang lainnya (Javed et al., 2013)

Keterampilan yang dikembangkan pada tingkat Sekolah Dasar salah satunya adalah keterampilan menulis. Menulis merupakan kegiatan menyampaikan ide atau gagasan kepada orang lain melalui suatu tulisan. Rukayah (2013) menyatakan bahwa menulis merupakan bentuk dari kecakapan seseorang utuk menyampaikan pesan atau informasi kepada orang lain melalui lambang grafik yang dapat dimengerti maksud serta maknanya. Hasil akhir dari proses menulis menjadi sebuah karangan.

Karangan terdiri atas beberapa bentuk. Salah satu bentuk karangan adalah karangan narasi. Karangan narasi adalah suatu bentuk wacana yang berusaha menggambarkan suatu cerita atau peristiwa untuk menginformasikan atau menghibur pembaca(Latifah \& Rahmawati, 2019).

Berdasarkan pengamatan pada peserta didik kelas V SDN Soko 1 masih banyak peserta didik yang masih kesulitan saat menulis karangan narasi. Hal ini dikarenakan peserta didik kurang memahami materi menulis narasi. Selain itu kegiatan pembelajaran menulis narasi yang dilakukan kurang variatif sehingga menyebabkan peserta didik merasa jenuh dan kurang tertarik pada saat menerima pembelajaran. Pembelajaran masih berpusat pada guru dan peserta didik kurang aktif dalam mengikuti pembelajaran.

Berdasarkan hasil tes pratindakan rendahnya keterampilan menulis dikarenakan peserta didik kesulitan menyampaikan pemikiran menjadi bentuk tulisan. Berdasarkan hasil pratindakan terhadap 12 peserta didik terdapat 375 peserta didik atau $75 \%$ yang belum mencapai nilai KKM $(\geq 75)$. Hasil pratindakan menunjukkan bahwa peserta didik masih kesulitan menggunakan Ejaan dengan benar. Selain itu juga kosakata yang dipilih peserta didik kurang tepat. Penulisan organisasi kalimat sesuai yang tepat serta urutan kalimat sehingga menjadi karangan narasi yang baik juga masih perlu diperbaiki.

Terkait dengan masalah tersebut, guru diharapkan untuk memodifikasi kegiatan pembelajaran agar peserta didik menjadi lebih bersemangat dalam melaksanakan pembelajaran di kelas serta lebih memahami materi pembelajaran dengan baik. Kegiatan pembelajaran yang bisa diterapkan yaitu dengan menerapkan model pembelajaran yang sesuai dengan karakteristik dari peserta didik dan juga materi yang ingin disampaikan. Penggunaan model pembelajaran yang tepat diperlukan agar dapat membantu guru dalam memperjelas dari langkah-langkah pembelajaran, hubungan, serta keadaan dari model yang telah didesain. Selain itu, penggunaan pembelajaran yang kooperatif akan menajdikan peserta didik lebih baik dalam berinteraksi dan 
bekerja sama dengan kelompoknya (Sari, 2014). Salah satu model pembelajan inovatif yang dapat diterapkan untuk meningkatkan keterampilan menulis karangan narasi adalah model Concept Sentence.

Concept Sentence merupakan model pembelajaran yang mengajarkan agar peserta didik dapat mengembangkan ide atau gagasan mengenai suatu objek melalui kata kunci yang sudah didapatkan hingga menjadi kalimat yang runtut. Hal ini sependapat dengan yang disampaikan oleh Huda (2014) bahwa model pembelajaran Concept Sentence mengajarkan kepada peserta didik untuk menulis suatu kalimat dengan menggunakan beberapa kata kunci yang didapatkan agar kalimat satu dengan kalimat lain mempunyai kandungan konsep yang berbeda.

Penerapan model Concept Sentence diharapkan dapat membantu meningkatkan keterampilan peserta didik dalam membuat sebuah karangan narasi. Penggunaan model ini, isi yang terdapat pada masing-masing kalimat dalam karangan narasi dapat mempunyai konsep yang berbeda anatrpeserta didikdan karangan yang dibuat menjadi lebih runtut. Selain itu, prinsip dari Model Pembelajaran Concept Sentence adalah bagaimana peserta didik mampu memanfaatkan kata kunci atau petunjuk yang disediakan (Fajriani, 2017). Pembuatan kata kunci tersebut berdasarkan peristiwa yang akan dinarasikan, sehingga isi karangan dapat menjadi lebih nyata.

Berdasarkan penelitian dari Utomo (2006) membuktikan bahwa penggunaan model Concept Sentence dapat meningkatkan keterampilan menulis pantun pada peserta didik kelas IV SD N Bumi I No. 67 Surakarta Tahun 2016. Selanjutnya, berdasarkan hasil temuan dari Purwanto (2014) bahwa model pembelajaran Concept Sentence dapat meningkatkan keterampilan menulis deskripsi SD N 01 Bolon Colomadu Karanganyar tahun ajaran 2013/2014.

Berdasarkan uraian di atas maka rumusan masalah dalam penelitian ini, antara lain: 1) Bagaimana penerapan model pembelajaran Concept Sentence dalam meningkatkan keterampilan menulis narasi di kelas V SD Negeri Soko 1 tahun ajaran 2020/2021? 2) Apakah model pembelajaran Concept Sentence dapat meningkatkan keterampilan menulis narasi di kelas V SD Negeri Soko 1 tahun ajaran 2020/2021?.

Berdasarkan uraian di atas, maka penelitian ini bertujuan untuk: 1) mendeskripsikan penerapan model pembelajaran Concept Sentence dalam peningkatan keterampilan menulis narasi di kelas V SD Negeri Soko 1 Sragen tahun ajaran 2020/2021. 2) Meningkatkan keterampilan menulis narasi menggunakan model pembelajaran Concept Sentence di kelas V SD Negeri Soko 1 Sragen tahun ajaran 2020/2021.

\section{METODE}

Penelitian ini merupakan Penelitian Tindakan Kelas (PTK) dengan model siklus. Tahapan Penelitian Tindakan Kelas terdiri dari perencanaan, pelaksanaan, pengamatan, dan refleksi. Subjek penelitian ini yaitu guru dan peserta didik kelas $\mathrm{V}$ SDN Soko 1 tahun ajaran 2020/2021. Sumber data pada penelitian ini menggunakan sumber data primer dan sumber data sekunder. Sumber data primer yaitu, guru, proses pembelajaran di kelas dan peserta didik kelas V. Sedangkan sumber data sekunder yaitu hasil wawancara, dokumentasi serta arsip nilai keterampilan menulis narasi. Penelitian ini menggunakan teknik tes, dokumentasi, observasi serta wawancara. Teknik pengumpulan dilakukan dengan angket saat observasi dan tes secara tertulis. Teknik analisis data menggunakan analisis data interaktif Miles dan Huberman.

\section{HASIL DAN PEMBAHASAN}

Penelitian ini merupakan Penelitian Tindakan Kelas dengan tiga siklus menggunakan model Concept Sentence. Tahapan penggunaan model pembelajaran Concept Sentence yaitu: 1) penyampaian tujuan kompetensi; 2) penjelasan materi ; 3) 
pembentukan kelompok dengan anggota yang heterogen; 4) Pemberian kata kunci sesuai dengan materi; 5) tiap kelompok membuat kalimat berdasarkan kata kunci; 6) hasil dari diskusi kelompok didiskusikan lagi secara pleno dan dipandu oleh guru.

Berdasarkan hasil tes pratindakan, menunjukkan bahwa masih terdapat 9 dari 12 peserta didik yang belum mencapai nilai KKM yaitu $\geq 75$. Tabel 1 berikut merupakan distribusi frekuensi nilai uji pratindakan keterampilan menulis deskripsi.

Tabel 1. Distribusi Frekuensi Nilai Uji Pratindakan Keterampilan Menulis Deskripsi

\begin{tabular}{|c|c|c|c|c|c|c|}
\hline \multirow{2}{*}{ No } & \multirow{2}{*}{ Interval Nilai } & \multirow{2}{*}{$\begin{array}{c}\begin{array}{c}\text { Frekuensi } \\
\left(\mathrm{f}_{\mathrm{i}}\right)\end{array} \\
\end{array}$} & \multirow{2}{*}{$\begin{array}{c}\text { Nilai Tengah } \\
\left(\mathbf{x}_{\mathrm{i}}\right)\end{array}$} & \multirow{2}{*}{ fi. $x_{i}$} & \multicolumn{2}{|c|}{ Persentase \% } \\
\hline & & & & & Relatif & Komulatif \\
\hline 1. & $35-42$ & 1 & 38,5 & 38,5 & 8,33 & 8,33 \\
\hline 2. & $43-50$ & 1 & 46,5 & 46,5 & 8,33 & 16,66 \\
\hline 3. & $51-58$ & 1 & 54,5 & 54,5 & 8,33 & 24,99 \\
\hline 4. & $59-66$ & 4 & 62,5 & 250 & 33,33 & 58,32 \\
\hline 5. & $67-74$ & 2 & 69,5 & 139 & 16,67 & 74,99 \\
\hline 6. & $75-82$ & 3 & 78,5 & 235,5 & 25,00 & 100 \\
\hline & Jumlah & 12 & & 764 & & \\
\hline Rat & -rata & & & 63,75 & & \\
\hline Nila & Tertinggi & & & 80 & & \\
\hline Nila & Terendah & & & 40 & & \\
\hline Ketı & ntasan Klasikal & & & $25 \%$ & & \\
\hline Nila & di bawah KKM & & & $75 \%$ & & \\
\hline
\end{tabular}

Tabel 1 tersebut menunjukkan bahwa dari 12 peserta didik, terdapat 3 atau 25\% peserta didik tuntas KKM, sedangkan yang belum tuntas KKM sebesar 9 atau $75 \%$ peserta didik. Nilai rata-rata peserta didik yaitu 63,75 dengan nilai tertinggi 80 dan nilai terendahnya 40.

Setelah dilaksanakan siklus I, hasil nilai keterampilan menulis narasi peserta didik meningkat. Nilai tersebut dapat dilihat pada tabel 2 berikut ini.

Tabel 2. Distribusi Frekuensi Nilai Keterampilan Menulis Deskripsi pada Siklus I

\begin{tabular}{|c|c|c|c|c|c|c|}
\hline \multirow{2}{*}{ No } & \multirow{2}{*}{ Interval Nilai } & \multirow{2}{*}{$\begin{array}{c}\text { Frekuensi } \\
\left(\mathrm{f}_{\mathrm{i}}\right)\end{array}$} & \multirow{2}{*}{$\begin{array}{c}\text { Nilai Tengah } \\
\left(\mathbf{x}_{\mathbf{i}}\right)\end{array}$} & \multirow{2}{*}{ fi. $x_{i}$} & \multicolumn{2}{|c|}{ Persentase \% } \\
\hline & & & & & Relatif & Komulatif \\
\hline 1. & $51-56$ & 1 & 53,5 & 53,5 & 8,33 & 8,33 \\
\hline 2. & $57-62$ & 2 & 59,5 & 119 & 16,66 & 30 \\
\hline 3. & $63-68$ & 1 & 65,5 & 65,5 & 8,33 & 38,33 \\
\hline 4. & $69-74$ & 1 & 71,5 & 71,5 & 8,33 & 41,66 \\
\hline 5. & $75-80$ & 6 & 77,5 & 465 & 50 & 91,66 \\
\hline 6. & $81-86$ & 1 & 83,5 & 83,5 & 8,33 & 100 \\
\hline & Jumlah & 12 & & 930 & & \\
\hline Rat & rata & & & 72,5 & & \\
\hline Nila & Tertinggi & & & 85 & & \\
\hline Nila & Terendah & & & 55 & & \\
\hline Ket & tasan Klasikal & & & $58,33 \%$ & & \\
\hline Nila & di bawah KKM & & & $41,67 \%$ & & \\
\hline
\end{tabular}


Tabel 2 tersebut menunjukkan bahwa pada siklus I terdapat 7 atau 58,33\% peserta didik tuntas KKM, sedangkan yang belum tuntas KKM sebesar 6 atau 41,67\% peserta didik. Nilai rata-rata peserta didik yaitu 72,5 dengan nilai tertinggi 85 dan nilai terendahnya 55.

Hasil nilai keterampilan menulis narasi pada siklus II mengalami peningkatan dibandingkan dengan siklus I. Tabel 3 berikut merupakan distribusi nilai pada siklus II

Tabel 3. Distribusi Frekuensi Nilai Keterampilan Menulis Deskripsi pada Siklus II

\begin{tabular}{|c|c|c|c|c|c|c|}
\hline \multirow{2}{*}{ No } & \multirow{2}{*}{$\begin{array}{c}\text { Interval } \\
\text { Nilai }\end{array}$} & \multirow{2}{*}{$\begin{array}{c}\text { Frekuensi } \\
\qquad\left(\mathbf{f}_{\mathrm{i}}\right) \\
\end{array}$} & \multirow{2}{*}{$\begin{array}{c}\text { Nilai } \\
\text { Tengah } \\
\left(\mathbf{x}_{\mathbf{i}}\right) \\
\end{array}$} & \multirow{2}{*}{ fi. $x_{i}$} & \multicolumn{2}{|c|}{ Persentase \% } \\
\hline & & & & & Relatif & Komulatif \\
\hline 1. & $57-62$ & 1 & 59,5 & 59,5 & 8,33 & 8,33 \\
\hline 2. & $63-68$ & 0 & 65,5 & 0 & 0 & 8,33 \\
\hline 3. & $69-74$ & 2 & 71,5 & 143 & 16,67 & 25,00 \\
\hline 4. & $75-80$ & 5 & 77,5 & 387,5 & 41,67 & 66,67 \\
\hline 5. & $81-86$ & 3 & 83,5 & 250,5 & 25,00 & 91,67 \\
\hline 6. & 87-92 & 1 & 89,5 & 89,5 & 8,33 & 100 \\
\hline \multicolumn{2}{|c|}{ Jumlah } & 12 & & 930 & & \\
\hline \multicolumn{2}{|c|}{ Rata-rata } & & & 78,33 & & \\
\hline \multicolumn{2}{|c|}{ Nilai Tertinggi } & & & 90 & & \\
\hline \multicolumn{2}{|c|}{ Nilai Terendah } & & & 60 & & \\
\hline \multicolumn{3}{|c|}{ Ketuntasan Klasikal } & & 75 & & \\
\hline \multicolumn{3}{|c|}{ Nilai di bawah KKM } & & 25 & & \\
\hline
\end{tabular}

Tabel 3 tersebut menunjukkan bahwa pada siklus II terdapat 8 atau $75 \%$ peserta didik tuntas KKM, sedangkan yang belum tuntas KKM sebesar 4 atau 25\% peserta didik. Nilai rata-rata peserta didik yaitu 78,33 dengan nilai tertinggi 90 dan nilai terendahnya 60.

Hasil nilai keterampilan menulis narasi pada siklus III mengalami peningkatan dibandingkan dengan siklus II. Tabel 4 berikut merupakan distribusi nilai pada siklus III.

Tabel 4. Distribusi Frekuensi Nilai Keterampilan Menulis Deskripsi pada Siklus II

\begin{tabular}{|c|c|c|c|c|c|c|}
\hline \multirow{2}{*}{ No } & \multirow{2}{*}{ Interval Nilai } & \multirow{2}{*}{$\begin{array}{c}\text { Frekuensi } \\
\left(f_{i}\right)\end{array}$} & \multirow{2}{*}{$\begin{array}{c}\text { Nilai Tengah } \\
\left(\mathbf{x}_{\mathrm{i}}\right)\end{array}$} & \multirow{2}{*}{ fi. $x_{i}$} & \multicolumn{2}{|c|}{ Persentase \% } \\
\hline & & & & & Relatif & Komulatif \\
\hline 1. & $63-68$ & 1 & 65,5 & 65,5 & 8,33 & 8,33 \\
\hline 2. & $69-74$ & 0 & 71,5 & 0 & 0,00 & 8,33 \\
\hline 3. & $75-80$ & 4 & 77,5 & 310 & 33,33 & 41,66 \\
\hline 4. & $81-86$ & 4 & 83,5 & 334 & 33,33 & 75,00 \\
\hline 5. & $87-92$ & 2 & 89,5 & 179 & 16,67 & 91,67 \\
\hline 6. & $93-98$ & 1 & 95,5 & 95,5 & 8,33 & 100,00 \\
\hline & Jumlah & 12 & & 984 & & \\
\hline Rato & -rata & & & 82,5 & & \\
\hline Nila & Tertinggi & & & 95 & & \\
\hline Nila & Terendah & & & 65 & & \\
\hline Kett & ntasan Klasikal & & & $92 \%$ & & \\
\hline Nila & di bawah KKM & & & $8 \%$ & & \\
\hline
\end{tabular}


Tabel 4 tersebut menunjukkan bahwa pada siklus III terdapat 11 atau 92\% peserta didik tuntas KKM, sedangkan yang belum tuntas KKM sebesar 1 atau $8 \%$ peserta didik. Nilai rata-rata peserta didik yaitu 82,5 dengan nilai tertinggi 95 dan nilai terendahnya 65 . Berdasarkan hasil tersebut maka penelitian dinyatakan berhasil dan tindakan dihentikan pada siklus III. Perbandingan nilai keterampilan menulis narasi peserta didik pada pratindakan, siklus I, siklus II dan siklus III dapat dilihat pada tabel 5 berikut.

Tabel 5. Perbandingan Nilai Keterampilan Menulis Narasi pada Pratindakan, Siklus I, Siklus II, dan Siklus III

\begin{tabular}{llllll}
\hline No & Keterangan & Pratindakan & Siklus I & Siklus II & Siklus III \\
\hline 1. & Nilai Rata-rata & 63,75 & 72,5 & 78,33 & 82,5 \\
2. & Ketuntasan Klasikal & $25 \%$ & $58,33 \%$ & $75 \%$ & $91,67 \%$ \\
\hline
\end{tabular}

Tabel 5 menunjukkan peningkatan nilai rata rata dari 63,75 pada pratindakan, meningkat menjadi 72,5 pada siklus I, 78,33 di siklus II dan 82,5 di siklus III. Ketuntasan klasikal juga meningkat dari $25 \%$ pada pratindakan menjadi $58,33 \%$ pada siklus I, menjadi 75\% di siklus II, dan pada siklus III meningkat menjadi 91,67\%. Maka dapat dapat diambil kesimpulan bahwa nilai keterampilan menulis narasi mulai dari pratindakan hingga siklus III mengalami peningkatan.

Pembelajaran pada siklus III telah berhasil mencapai indikator kinerja penelitian yang ditetapkan, akan tetapi masih terdapat 1 peserta didik yang belum mencapai KKM. Berdasarkan observasi, peserta didik tersebut cenderung kurang memperhatikan penjelasan dari guru dan kemampuan menulisnya tergolong rendah. Upaya yang dilakukan terhadap peserta didik yang belum tuntas dengan memberikan bimbingan serta memotivasi peserta didik agar lebih memperhatikan pembelajaran dengan baik.

Berdasarkan uraian di atas dapat disimpulkan bahwa penggunaan model Concept Sentence dapat meningkatkan keterampilan menulis narasi peserta didik kelas V SD Negeri Soko 1 tahun ajaran 2020/2021. Setelah diterapkan model Concept Sentence pada siklus I, siklus II, dan siklus III, peserta didik mengalami peningkatan keterampilan menuis deskripsi. Penggunaan model Concept Sentence dapat membantu peserta didik dalam mengembangkan kreativitas peserta didik dalam menulis berdasarkan kata kunci yang diterima (Aminah, 2017). Penggunaan model Concept Sentence juga dapat membuat peserta didik mendalami kata kunci dari materi pokok yang diberikan (Siswanto \& Ariani, 2016). Hal tersebut dikarenakan kata kunci yang telah diberikan berisi tentang poin-poin penting dari materi yang akan dipelajari.

\section{SIMPULAN}

Berdasarkan hasil penelitian yang telah dilaksanakan, maka dapat disimpulkan bahwa penggunaan model pembelajaran Concept Sentence dapat meningkatkan hasil keterampilan menulis narasi pada peserta didik kelas II SD Negeri Soko 1. Model pembelajaran Concept Sentence dalam peningkatan keterampilan menulis narasi peserta didik kelas V SD Negeri Soko 1 dilaksanakan dengan tahapan 1) penyampaian tujuan kompetensi; 2) penjelasan materi ; 3) pembentukan kelompok dengan anggota yang heterogen; 4) Pemberian kata kunci sesuai dengan materi; 5) tiap kelompok membuat kalimat berdasarkan kata kunci; 6) hasil dari diskusi kelompok didiskusikan lagi secara pleno dan dipandu oleh guru.

Implikasi berdasarkan hasil penelitian secara teoretis yaitu dapat dijadikan referensi bagi peneliti lain dalam penerapan model Concept Sentence khususnya 
materi menulis narasi. Implikasi praktis hasil penelitian ini yaitu menunjukkan bahwa dengan menerapkan model pembelajaran yang inovatif dapat berpengaruh dalam meningkatkannya nilai keterampilan menulis peserta didik. Saran bagi penelitian lain sebaiknya menambah kajian teori, sumber pustaka dan rujukan yang lebih lengkap serta penggunaan media pembelajaran yang efektif dan efisien untuk mengoptimalkan kualitas dalam pembelajaran.

\section{DAFTAR PUSTAKA}

Aminah, S. (2017). Penerapan Model Concept Sentence dengan Media Flashcard untuk Meningkatkan Keterampilan Menulis Puisi pad Siswa Sekolah Dasar. Didaktika Dwija Indria, 5 (12).

Fajriani, R. (2017). Meningkatkan Keterampilan Menulis Paragraf Melalui Penerapan Model Pembelajaran Concept Sentence Dengan Permainan Detective Sherlock Holmes and the Adventure Book. Jurnal Pena IImiah, 2(1), 161-170.

Huda, M. (2014). Model-Model Pengajaran dan Pembelajaran Isu-Isu Metodis dan Pragmatis. Yogyakarta : Pustaka Pelajar.

Javed, M., Juan, W. X., Nazli, S., Princpal, V., Oxford, M., High, C., \& Vehari, S. (2013). Study of Students' Assessment in Writing Skills. International Journal of Instruction, 6(2), 129-144.

Latifah, N., \& Rahmawati, I. N. (2019). Teaching And Learning Narrative Text Writing Through Story Mapping. English Education: Jurnal Tadris Bahasa Inggris, 12(1), 78-96.

Purwanto, D. (2014). Model Pembelajaran Concept Sentence Untuk Meningkatkan Keterampilan Menulis Deskripsi. Didaktika Dwija Indria, 2, No 11.

Rukayah. (2013). Pedoman Pelaksanaan Pembelajaran Menulis dengan Pendekatan Whole Language di Sekolah Dasar. Surakarta : UNS Press.

Sari. (2014). Keefektifan Model Concept Sentence Terhadap Aktivitas Dan Hasil Belajar Menulis Narasi. Journal of Elementary Education, 3(1), 6-12.

Siswanto, \& Ariani. (2016). Model Pembelajaran Menulis Cerita. Bandung : Refika Aditama.

Slamet. (2014). Pembelajaran Bahasa dan Sastra Indonesia di Kelas Rendah dan Tinggi Sekolah Dasar. Surakarta : UNS Press.

Tarigan, H. G. (2008). Menulis Sebagai Suatu Keterampilan Bahasa. Bandung: Angkasa.

Utomo, U. (2006). Peningkatan Keterampilan Menulis Pantun Melalui Model Pembelajaran Concept Sentence. Didaktika Dwija Indria, 4, No 8. 